\title{
Mitigation of the effect of secondary salinization by micro soil conditioning
}

\author{
Arzu Rivera - Géza Tuba - Krisztina Czellér - Györgyi Kovács - József Zsembeli \\ Research Institute of Karcag, IAREF, University of Debrecen, 5300 Karcag, Kisújszállási út 166. Hungary \\ arzu173@hotmail.com
}

\begin{abstract}
SUMMARY
This research has the general goal to meet the customization of agriculture in small scale farming. We are developing a technique using micro doses of soil conditioners and organic material applied in the root zone of vegetable crops. We expected to change the physical and chemical properties of the affected soil, which has been irrigated with salty water. Two different soil conditioners were tested. A lysimeter experiment including 8 simple drainage lysimeters was set up in the Research Institute of Karcag IAREF University of Debrecen in 2017. The main goal was to study the effect of different soil conditioners on the soil endangered by secondary salinization induced by irrigation with saline water. In order to compare the difference between the treatments, we collected soil samples, water samples, and determined the yields. Chili pepper (Capsicum annuum) was used as an indicator crop during one specific agricultural season. The technique called micro soil conditioning is rational because several reasons. The roles of the technique are various, for example it can serve as a source of carbon or a container for soil amendments and can minimize evaporation. We found this technique not to interfere with the chemical reaction or the interaction with the plants. However, the micro doses of soil amendments had the role to minimize the risk of soil degradation and do not significantly influence soil respiration. In addition, by improving soil properties, soil conditioning increases the leaching of the excess of salts from the root zone. In fact, this technique can decrease the cost of the inputs and improves the production of vegetables, and at the same time mitigates the effect of secondary salinization.
\end{abstract}

Keywords: secondary salinization, mitigation, capsicum annuum

\section{INTRODUCTION}

The scarcity and degradation of land is more endangered in semiarid areas. Salinization is one of the problems, $30 \%$ land loss can be expected in the world for 2025 , with some estimates as high as $50 \%$ by 2050 (Wang et al., 2003). In these regions the major soil degradation threats are the mismanaged irrigation, affecting 34.19 million hectares over $10 \%$ of the total irrigated land (Lambert et al., 2002). As a result of irrigation, the salty water can percolate into the subsoil and the level of groundwater can rise near the surface (Martínez, 2002). The soils irrigated with high sodium or ground waters usually contain adsorbed sodium as well adsorbed calcium and magnesium, which has an effect on the soil called secondary salinization (Bower, 1959). Soil salinization is a general term including various soluble salts (cations such as $\mathrm{Na}^{+}, \mathrm{K}^{+}, \mathrm{Ca}^{2+}$ and $\mathrm{Mg}^{2+}$ along with anions $\mathrm{Cl}^{-}, \mathrm{SO}_{4}{ }^{2-}, \mathrm{NO}_{3}{ }^{-}, \mathrm{HCO}_{3}{ }^{-}$and $\mathrm{CO}_{3}{ }^{2-}$ ) that can affect soil and water in different ways (Daliakopoulos et al., 2016). The need of amendments to stop or mitigate the harmful effect is indispensable. Therefore, the determination of the amount and kind of amendments is the best to be ascertained by soil tests. Soil conditioners have been searched because the necessity for chemical and physical maintenance or enhancement of land and for the disposal or management of waste materials (Bower, 1959).

In this research we studied the possible mitigation of secondary salinization in the soils of the hobby gardens in Karcag, Hungary. Karcag is a semiarid place, where the soils often have an excess of salts, because the irrigation water is coming from salty underground water. In previous studies it was proven that the underground water in the area of Karcag is not suitable for irrigation (Zsembeli et al., 2013; Sinka et al., 2019). The hobby gardens have been utilized for horticultural activities for 300 years, so is a tradition to grow mainly vegetables and fruits for their consumptions there (Zsembeli et al., 2011). Nowadays low scale farming has different problems, where the interactions between agriculture and the environment can be especially unequal, as they are determined by the scarcity of land or resources (Fida and Pnuma, 2013).

The general aim of this work is to approach the customization of agriculture in small scale farming. We study the effect of different soil conditioners on the soil and the indicator crop under irrigation with saline water. We developed a technique by applying micro doses of soil conditioners and organic materials in the root zone, in order to change the physical and chemical properties of the topsoil, which has been affected by salts.

\section{MATERIALS AND METHODS}

In order to demonstrate that the micro doses of soil conditioners can change the physical and chemical properties of the soil water, we established a lysimeter experiment including 8 simple drainage lysimeters in the Research Institute of Karcag IAREF University of Debrecen in 2017. The lysimeters were filled with a meadow chernozem soil. We simulated the soil and irrigation conditions characteristic in the hobby gardens around Karcag.

According to the principle of the newly developed technique of micro soil conditioning, we made organic (recycled paper) baskets, which contained $500 \mathrm{~g}$ soil, the conditioners and the indicator plant (chilli pepper). The material of the baskets, paper has high $\mathrm{C}: \mathrm{N}$ ratio because of the wood fibre in general (O'Brien et al., 2002). We placed these sets into the topsoil (Figure 1). The main ingredients of the conditioners are clay minerals, trace minerals and organic nutrients 
originating from algae (Olmix group, 2018). Two soil conditioners were tested and their combination. Involving the untreated control, the experiment was set up with four treatments in two replications. In the control treatment, only N-P-K fertilizers were applied. The treatments of the experiment were as follows: control 3g of NPK, Physiomax (Physi) $13.5 \mathrm{~g}$, Solactive (Sola) $13.5 \mathrm{~g}$, Solactive plus Physiomax (Sola+Physi) $13.5 \mathrm{~g}+13.5 \mathrm{~g}$. Each treatment was equipped with three chili plants (in three baskets). The general requirements for the production of this plant make it suitable for being the indicator crop of the experiment, such as life cycle of one year, optimal temperature range from 20 to $25^{\circ} \mathrm{C}$ (min. $13^{\circ} \mathrm{C}$ and $\max .40^{\circ} \mathrm{C}$ ); cultivated in tropical, subtropical and tempered regions; soil with good drainage and rich in organic material; soil $\mathrm{pH}$ range 5-7; relative humidity of the air range $50-70 \%$ (Ramirez, 2002). The measured variables were the electric conductivity (EC) of the soil, soil temperature, and soil moisture content, all measured by means of an UMP-1 mobile probe.

Figure 1: Plantation of chili plants in the lysimeters (Karcag, 2017)
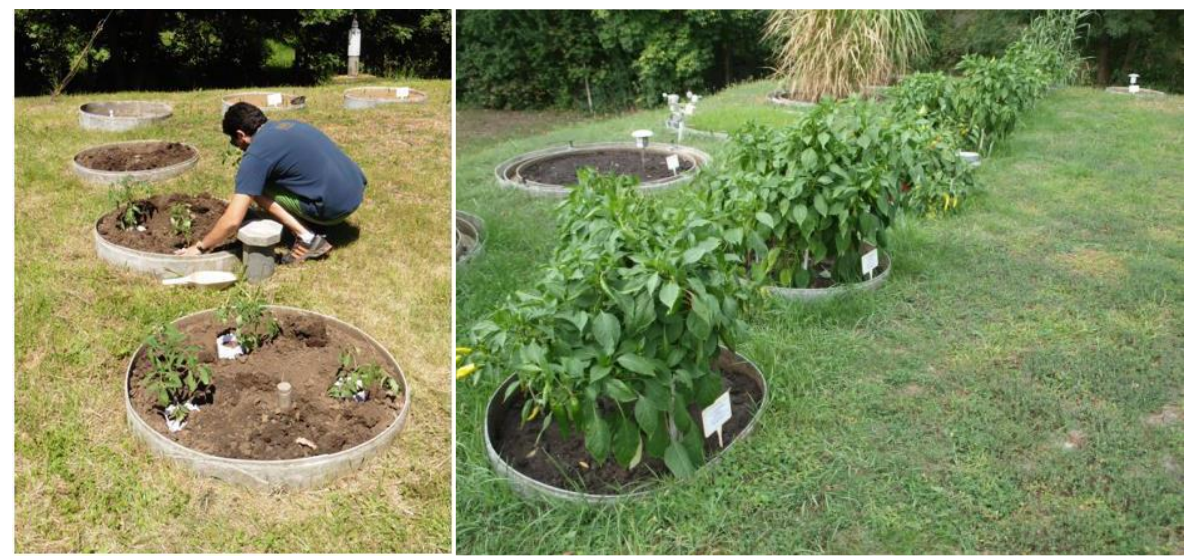

In order to evaluate the effect of the soil conditioners, we took soil samples from the lysimeters to compare the physical and chemical effect of the investigated micro soil conditioners in the topsoil. The samples were taken two times, first we took samples from the upper layer $(20 \mathrm{~cm})$ before setting the experiment. The second sampling was in the following spring. In the Central Laboratory of RIK IAREF UD the soil plasticity, NPK contents and salt content were measured. The first sampling contributed to determine the necessary fertilizer and soil conditioner doses need to be added to each treatment. After the harvest, we took soil samples down to $100 \mathrm{~cm}$ in order to study the leaching of salts to the deeper horizons. We identified 5 soil layers $(0-20 \mathrm{~cm}, 20-40 \mathrm{~cm}, 40-60 \mathrm{~cm}, 60-80 \mathrm{~cm}$, $80-100 \mathrm{~cm}$ ) and we measured the EC (which refers to the total soluble salt content of the soil) in each layer.

After harvest, we dried the fruits and the vegetative parts of the chilli plants separately in order to compare the effects of the soil conditioners on them. Also, we collected leachate water samples from the lysimeters in order to prove that the salts from the topsoil were leached or not. Finally, we used a statistic model in order to verify if there is a significance difference in the $\mathrm{EC}$ values from the top soil layer $(10 \mathrm{~cm})$ between the treatments. We used PSPPire.exe to run the one-way analysis of variance (ANOVA). This test allowed us to divide the variability of the groups of interest and compare the means between them (Winklers and Hays, 1975; Porras, 2001, Badii et al., 2012).

\section{RESULTS AND DISCUSSION}

\section{Results of soil analyses}

We speculated to have different reactions in the upper layer between the control and where soil conditioners were applied. Table 1 shows the EC values of the top layer of the treatments. The EC value did not change in the control treatment during the time, in the case of the Sola treatment the final EC value was higher than the initial one, while in the Physi and Physi+Sola treatment decreased. However, these changes on the soil characteristic are too complex to be explained and we need more information in this respect. It is interesting that Sola+Physi combination behaved differently. Possibly Physi reacts with Sola conditioner boosting salt accumulation for while, but later also enhances leaching. It is known that irrigation induces changes in the physical, chemical and biological characteristics of the soil, but in this case the salt leaching depends not only on irrigation. The bond between clay and salts is altered by increasing organic matter and moisture. It is known that the addition of amendments causes drastic changes in the characteristics and qualities of soils (Maletic and Hutchings, 1967), but in this micro dose the soil slightly modifies the EC values. On the base of the statistical analyses, the standard deviation varied between each data point relative to the mean. For Sola+Physi treatment the variation was higher than for the other treatments. However, the range among the treatments is $0.97 \mathrm{mS} \mathrm{cm}^{-1}$, but the ANOVA test showed no significant difference between the treatments $(\mathrm{F}=1.75$ 
for the $\alpha$ 0.1). For instance, the control and the conditioned treatments are not different at all, that means that the EC value is changing during the time and the soil conditioners are not disturbing this natural variation. This is important in the environmental point of view because the native microorganisms are not influenced by rough changes with the application of micro doses of soil conditioners.

EC differences measured in the topsoil of the lysimeters (Karcag, 2017-2018)

\begin{tabular}{cccccc}
\hline $\begin{array}{c}\text { Treatment depth } \\
\text { 0-20cm }\end{array}$ & $\begin{array}{c}\text { EC }\left(\mathrm{mS} \mathrm{cm}^{-1}\right) \\
\text { July 2017 }\end{array}$ & $\begin{array}{c}\text { EC }\left(\mathrm{mS} \mathrm{cm}^{-1}\right) \\
\text { March 2018 }\end{array}$ & $\begin{array}{c}\text { Minimum } \\
\left(\mathrm{mS} \mathrm{cm}^{-1}\right)\end{array}$ & $\begin{array}{c}\text { Maximum } \\
\left(\mathrm{mS} \mathrm{cm}^{-1}\right)\end{array}$ \\
\hline Sola & 0.78 & 0.81 & 0.64 & 3.65 & 0.92 \\
Physi & 0.35 & 0.15 & 0.08 & 2.62 & 0.74 \\
Sola+Physi & 0.53 & 0.31 & 0.46 & 4.304 & 3.124 \\
Control & 0.75 & 0.75 & 0.75 & 0.78 \\
\hline
\end{tabular}

The salt profiles determined for the soils of the treatments reflect the distribution of the salts in the different soil layers (Figure 2). In this case, the irrigation water applied contains appreciable quantities of soluble salts and can lead to salinity problems by time. The comparison of the salt profiles of the treatment Sola and the control shows that the salts were not leached down at all from the upper layer. It is possible that the salt content of conditioner Sola was leached into the other layers, meanwhile the salts on the top layer remained like in the control. The soil profile of Physi reflects the action of a salt leaching down to the bottom $(80-100 \mathrm{~cm})$. Meanwhile the salt profile of Sola+Physi shows leaching of the salts, but it was less efficient than the other soil conditioner.

Figure 2: Salt profiles for each treatment in the lysimeter experiment (Karcag, 2018)

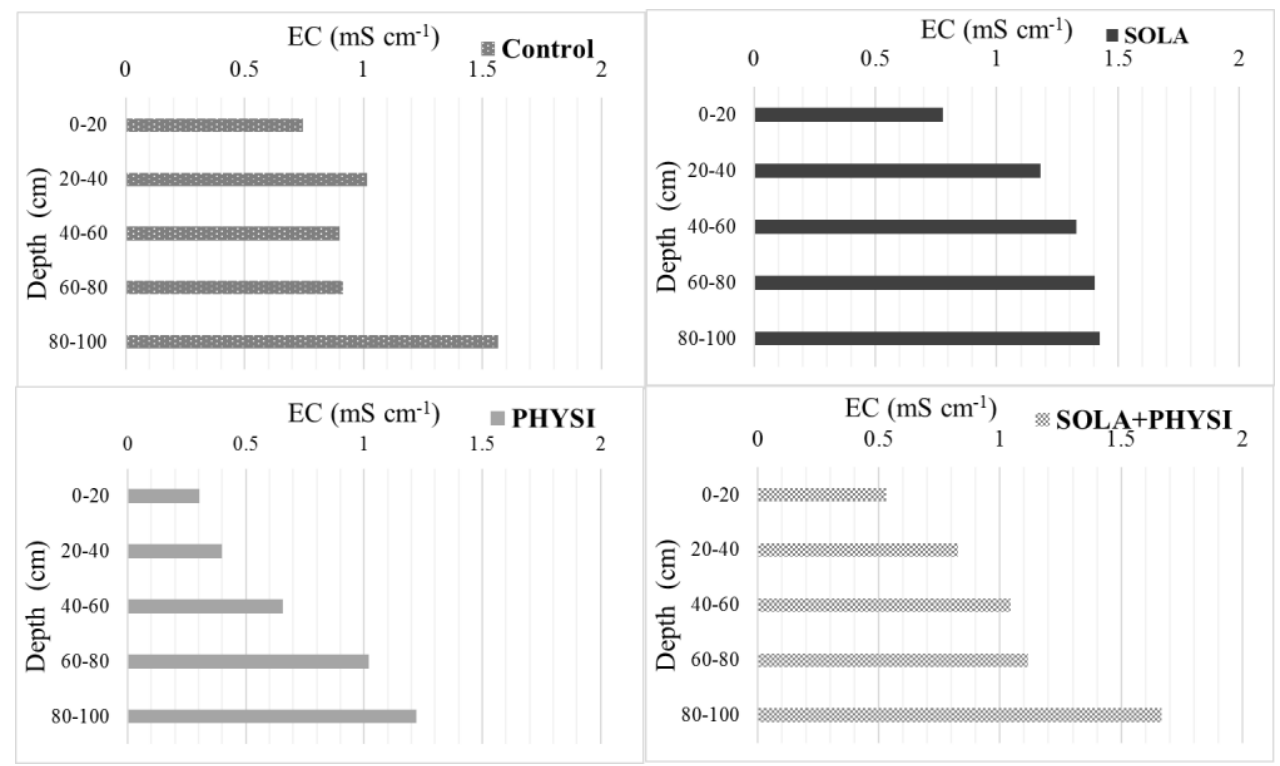

\section{Results of water analyses}

We collected the all the waters leached from the lysimeters (drain waters or leachates), we sampled them six times until the end of March of 2018, and their EC was measured in the laboratory. We expected high salt concentrations due to leaching from the treated soil columns. The first leachate appeared in November 2017, when the whole soil column was saturated over the field capacity and deep percolation occurred through the gravitation pores. The salt content of the leachates was slightly decreasing over the time, but they still had extremely high concentrations $(>3,000$ $\left.\mathrm{mg}^{-1}\right)$. Figure 3 shows the salt contents of the leachates at the monitoring dates. Sola+Physi was the treatment in which the water had more salts, because the salts from the conditioners and the salts from the top layer percolated. The Physi treatment and the control can be characterized with similar EC values all over the investigation period. The possible reason is that most of the Physi soil conditioner was degraded and absorbed in the top soil by microorganism and the plant. The remaining salts percolated to different levels just like in the case of the control. We also consider the accumulation of the organic material of the basket in 
the top soil can adsorb the salinity and make available nutrients to microorganisms or the roots. It must be mentioned that the organic baskets made of paper contain kaolinite. This clay mineral is used in papercoating. The characteristics of this mineral are low absorption and adsorption which is related to the low surface charge on the particles, which influence the activity of microorganisms such as buffering of soil $\mathrm{pH}$ within a favourable range for vital physiological perspective (Murray, 1991; Patra et al., 2016).

Figure 3: Salt contents in the leachates in the lysimeter experiment (Karcag, 2018)

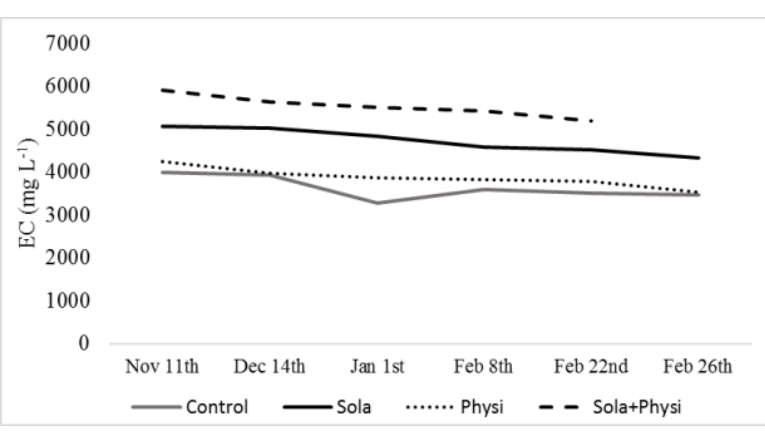

\section{Yield results}

The harvest of the chilli peppers was in October 2017. The plant and the fruits were dried and weighed. We compared the dry mass of the plants and the fruits from each treatment. In distinction, Physi treatment had the best improvement in the vegetative growth and

\section{CONCLUSION}

Zsembeli et al. (2019a) mentioned that the mitigation of the harmful effect of secondary salinization is possible and soil structure can be improved. The mitigation is a slow process, talks several years depending on the given conditions, but by means of proper irrigation and soil conditioner application the time can be shortened (Sinka et al., 2019). The results that we gained cover only one year, but big changes can be figured out in the soil regarding the microorganisms and $\mathrm{CO}_{2}$ concentration (Kovács, 2015). For example, Zsembeli et al. (2019b) treated different soil types with different soil conditioners finding that soil moisture content is the dominant factor that determines the microbiological activity of the soil. The effect of soil conditioners stimulates the $\mathrm{CO}_{2}$ concentration depending of the soil moisture content. It is known that the incorporation of fertilizers alters the soil air composition, especially if moisture and temperature conditions are optimal. Even though, the research review from Rath and Rousk (2015) mentioned that salinity is an important factor for microbial respiration. In fact, the respiration in soils is negatively correlated with salinity, but microbial respiration is complex and depends on other factors, like the carbon content of the soil, because the level of yield. However Sola+Physi treatment had the worst performance on the fruits. The effect of the soil conditioners had better performance in the vegetative part of the plants (Figure 4). Barrios et al. (2007) explained that the salt input into the soil causes 10-20\% loss of yield. In fact, it is not recommended to combine these two soil conditioners (Sola+Physi). An important characteristic to understand it is the phenology of the crop, the water demand and the efficient uptake of nutrients in each growing state of the plant. With this information we can reach the optimal production of the crop and the health of the soil. In fact, fertigation could be really efficient in water supply and nutrition uptake when is integrated with the development patterns of the plants avoiding secondary salinization (Yuncai et al., 2005).

Figure 4: Yield results of the experiment (Karcag, 2017)

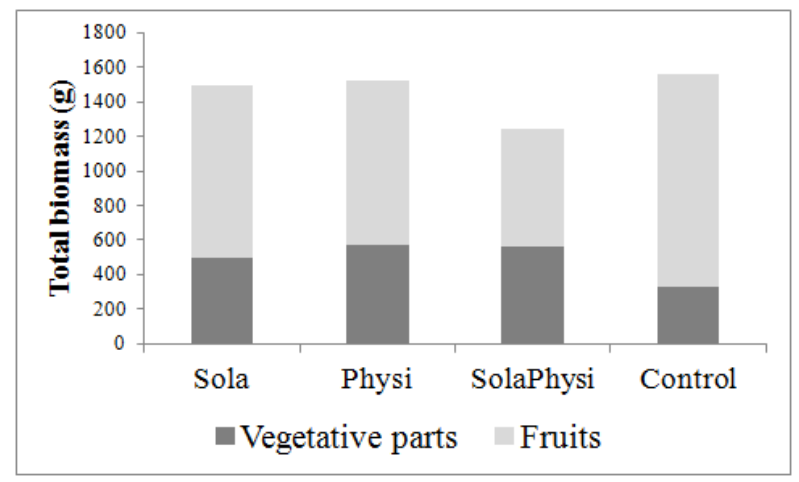

carbon determines the potential growth of the microbiota.

The possibility to mitigate the effect of secondary salinization by using micro doses of soil conditioners and organic materials is important for horticultural production. This technique has the possibility to change the soil properties of the root zone and mitigate the soil degradation by secondary salinization. Based on the results, we can mention several reasons why this technique is useful. First of all, the organic basket can restrict the area of soil conditioners focusing on the root zone and minimize the run off of the amendments. The paper basket is an input of organic material and kaolinite, which reduce the salt content in the top soil, while becoming a source of carbon. At the same time, we observed that the organic basket retains the humidity of the soil after irrigation. Likewise, the organic basket did not react with the soil conditioners or the fertilizers. The effect of micro doses of conditioners in the vegetative production was positive, as we expected. In addition, the micro doses of soil conditioners aided the leaching of the excess of salts from the root zone.

We propose the next step is to study this technique under field conditions and in the hobby gardens in Karcag. In future studies it can be essential to recognize the efficient amount of the applied conditioners into the 
root zone depending on the phenology of the plant. Other idea is to test the correlation between the micro conditioning and the germination rate of the seeds and between the microbiological activity of the soil.

The application of this technique is reliable to mitigate the harmful effects of secondary salinization in a sustainable way, but more experimental experiences are needed.

\section{ACKNOWLEDGEMENTS}

The research was financed by the Higher Education Institutional Excellence Programme (NKFIH-11506/2019) of the Ministry of Innovation and Technology in Hungary, within the framework of the $4^{\text {th }}$ thematic programme of the University of Debrecen.

\section{REFERENCES}

Badii, M. H.-Guillen, A.-Araiza, L. A.-Cerna, E.-Valenzuela, J.Landeros, J. (2012): Métodos No-Paramétricos de uso común. International Journal of Good Conscience. 7: 132-155.

Barrios, U.-Arredondo, C. B.-Tjalling, H. (2007): Guía de manejo de nutrición vegetal de especialidad: Pimiento SQM. México, D.F. 103.

Bower, C. (1959): Chemical Amendments. Agriculture Information. United States department of agriculture. Bulletin No. 195 http://krishikosh.egranth.ac.in/bitstream/1/2031877/1/59185.pdf Search engine: Google. Key words: Soil, salinization, chemical conditioners.

Daliakopoulos, I. N.-Tsanis, I. K.-Koutroulis, A.-Kourgialas, N. N.Varouchakis, A. E.-Karatzas, G. P.-Ritsema, C. J. (2016): The threat of soil salinity: A European scale review. Science of the Total Environment 573: 727-739.

Fida-Pnuma (2013): Smallholders, food security and the environment. Rome. FAO. On line in https://www.ifad.org/documents/38714170/39135645/smallhol ders_report.pdf/133e8903-0204-4e7d-a780-bca847933f2e

Kovács, Gy. (2015): Examination of Carbon-Dioxide Emission of Agricultural Lands in Karcag Region. University of Debrecen. Hungary. $26 \mathrm{pp}$.

Lambert, K.-Sedema, I.-Karim, S. (2002): Irrigation and salinity: a perspective review of the salinity hazards of irrigation development in the arid zone. Irrigation and Drainage Systems 16: $161-174$

Maletic, J.-Hutchings, T. B. (1967): Selection and Classification of Irrigable Land. In Irrigation of agricultural lands. American Society of Agronomy. 974-984.

Martínez, G. M. (2002): El cultivo de chile guajillo con fertirrigación en el Altiplano de San Luis Potosí. Secretaría de Agricultura, Ganadería, Desarrollo Rural, Pesca y Alimentación, Instituto Nacional de Investigaciones, Forestales, Agricolas y Pecuarias. Campo Experimental Palma de la Cruz. San Luis, Potosí, México. 11.

Murray, H. (1991): Overview-clay mineral applications. Applied Clay Science 5: 379-395.

O'Brien, T. A.-Herbert, S. J.-Barker, V. A. (2002): Mixtures of paper mill sludge and soil. Commun. Soil. Sci. Plant Anal. 33: 635-646.

Olmix group. (2018): The Power of Algae, Serving The Planet. France. 12. On line in https://www.olmix.com/sites/default/files/brochure.olmix_grou p.corporate.en.pdf
Patra, A. K.-Adhikari, T.-Bhardwaj, A. K. (2016): Enhancing Crop Productivity in Salt-Affected Environments by Stimulating Soil Biological Processes and Remediation Using Nanotechnology 83-104. In J.C. Dagar-P.C. Sharma-D.K. Sharma-A.K. Singh (Editors) Inovative Saline Agriculture. Springer, India.

Porras, L. A. (2001): Diseño estadístico de experimentos, análisis de la varianza y temas relacionados: tratamiento informático mediante SPSS". Ed.: Proyecto sur. P. 15.

Ramirez, J. (2012): Chile. http://www.biodiversidad.gob.mx/ usos/alimentacion/chile.html Search engine: Google. Key words: Capsicum annumm, chile, origen, biodiversidad.

Rath, M.-Rousk, J. (2015): Salt effects on the soil microbial decomposer community and their role in organic carbon cycling: A review. Soil Biology \& Biochemistry. 81: 108-123.

Sinka, L.-Rivera-Garcia, A.-Tuba, G.- Zsembeli, J. (2019): Mitigation of salt stress caused by secondary salinization. In: XX. stiavnické dni 2019: Zborník recenzovanych príspevkov pp. 254-262.

Wang, W.-Vinocur, B.-Altman, A. (2003): Plant responses to drought, salinity and extreme temperatures: towards genetic engineering for stress tolerance. Planta, 218: 1-14.

Winkler, R. L.-Hays, W. (1975): Statistics: Probability, Inference, and Decision. New York: Holt, Rinehart and Winston. 761.

Yuncai, H.-Dieter, G.-Urs, S. (2005): Interactive Effects of Nutrients ad Salinity and Drought on Weath Growth. Symposium on Fertigation Optimizing the utilization of water and nutrients Beijing, 179-183.

Zsembeli, J.-Szücs, L.-Blaskó, L. (2011): Secondary salinization by irrigation from drilled wells in Karcag area. $10^{\text {th }}$ Alps-Adria Scientific Workshop.

Zsembeli, J.-Kovács, G.-Szücs, L.-Tóth, J. (2013): Examination of Secondary Salinization in Simple Drainage Lysimeters. Gumpensteiner Lysimetertagung. 153-156.

Zsembeli, J.-Sinka, L.-Rivera-García, A.-Czellér, K.-Tuba, G.Koloman, K.- Findura, P. (2019a): Effect of soil conditioning on the moisture content and the salt profile of the soil under irrigation with saline water polnohospodarstvo-agriculture 2019: 65 pp. 77-87.

Zsembeli, J.-Rivera-García, A.-Zsembeli, Zs.-Kovács, Gy.-Czellér, K.-Tuba, G. (2019b): Examination of the effect of soil conditioning on the microbiological activity of three different soil types in a pot experiment. $2^{\text {nd }}$ Conference on Long-Term Field Experiments. 39-44. 
